\title{
Potential enhancement of osteoclastogenesis by severe acute respiratory syndrome coronavirus $3 \mathrm{a} / \mathrm{X} 1$ protein
}

\author{
Saemi Obitsu - Nursarat Ahmed · Hironori Nishitsuji - Atsuhiko Hasegawa • \\ Ken-ichi Nakahama · Ikuo Morita · Kazuo Nishigaki · Takaya Hayashi · \\ Takao Masuda $\cdot$ Mari Kannagi
}

Received: 2 February 2009/ Accepted: 13 July 2009/Published online: 14 August 2009

(C) Springer-Verlag 2009

\begin{abstract}
Severe acute respiratory syndrome coronavirus (SARS-CoV) causes a lung disease with high mortality. In addition, osteonecrosis and bone abnormalities with reduced bone density have been observed in patients following recovery from SARS, which were partly but not entirely explained by the short-term use of steroids. Here, we demonstrate that human monocytes, potential precursors of osteoclasts, partly express angiotensin converting enzyme 2 (ACE2), a cellular receptor of SARS-CoV, and that expression of an accessory protein of SARS-CoV, $3 \mathrm{a} / \mathrm{X} 1$, in murine macrophage cell line RAW264.7 cells, enhanced NF- $\kappa$ B activity and differentiation into osteoclast-like cells in the presence of receptor activator of $\mathrm{NF}-\kappa \mathrm{B}$ ligand (RANKL). Furthermore, human epithelial A549 cells expressed ACE2, and expression of $3 \mathrm{a} / \mathrm{X} 1$ in these cells up-regulated TNF- $\alpha$, which is known to accelerate osteoclastogenesis. $3 \mathrm{a} / \mathrm{X} 1$ also enhanced RANKL
\end{abstract}

S. Obitsu · N. Ahmed · H. Nishitsuji - A. Hasegawa ·

K. Nishigaki · T. Hayashi · T. Masuda · M. Kannagi ( $\square)$

Department of Immunotherapeutics, Tokyo Medical and Dental

University Graduate School, 1-5-45 Yushima, Bunkyo-ku,

Tokyo 113-8519, Japan

e-mail: kann.impt@tmd.ac.jp

K. Nakahama · I. Morita

Department of Cellular Physiological Chemistry,

Tokyo Medical and Dental University Graduate School,

Tokyo, Japan

I. Morita

Global Center of Excellence Program, International Research

Center for Molecular Science in Tooth and Bone Diseases,

Tokyo Medical and Dental University Graduate School,

Tokyo, Japan

K. Nishigaki

Department of Veterinary Medicine, Yamaguchi University,

Yamaguchi, Japan expression in mouse stromal ST2 cells. These findings indicate that SARS-CoV $3 \mathrm{a} / \mathrm{X} 1$ might promote osteoclastogenesis by direct and indirect mechanisms.

\section{Introduction}

In 2002-2003, over 8,000 people were affected by severe acute respiratory syndrome (SARS) caused by SARS coronavirus (SARS-CoV), and about $10 \%$ of these patients died of rapidly progressing dyspnea and systemic failure [1-3]. Pathological characteristics of SARS, such as epithelial cell proliferation and an increase in macrophages with frequent hemophagocytosis in the lung, suggest that dysregulation of proinflammatory cytokine production in macrophages may account for SARS pathogenesis [4]. Many patients were treated with high-dose steroids, and this provided a clinical benefit to some extent.

Sometime after the outbreak, several reports indicated high frequency of arthralgia and reduced bone density in patients who recovered from SARS [5, 6]. Radiological lesions included osteonecrosis of femurs and tibiae and additional nonspecific subchondral and intramedullary bone marrow abnormalities [6]. Although the risk of osteonecrosis was higher in the patients receiving a higher dose of steroids, the other bone abnormalities were independent of steroid dose [6].

The balance between bone resorption by osteoclasts and bone formation by osteoblasts is important for bone homeostasis and remodeling [7]. Osteoclasts are derived from precursor cells of the myeloid lineage, and interaction between receptor activator of NF- $\kappa$ B ligand (RANKL) and RANK on bone marrow monocyte/macrophages is essential for osteoclast differentiation $[8,9]$. RANKL is a TNF superfamily cytokine produced by various kinds of cells 
including osteoblasts and activated T cells [7]. A subset of peripheral blood monocytes also differentiate into osteoclasts in the presence of RANKL and M-CSF in vitro [10]. In addition, various inflammatory cytokines such as TNF- $\alpha$ promote osteoclastogenesis [11, 12]. Since inflammatory responses are associated with SARS, and macrophages are susceptible to SARS-CoV in vitro [13], we hypothesized that SARS-CoV infection might promote osteoclastogenesis.

The SARS-CoV genome encodes several accessory proteins without sequence similarity to known coronavirus proteins $[14,15]$. We previously reported that, among the SARS-CoV accessory proteins, $3 \mathrm{a} / \mathrm{X} 1$ strongly augmented chemokine production by activating NF- $\kappa \mathrm{B}$, a critical transcription factor for inflammatory responses [16]. Similar effects of $3 \mathrm{a} / \mathrm{X} 1$ protein on NF- $\kappa \mathrm{B}$ activation, especially in the presence of double-strand RNA, has been reported [17].

In the present study, we demonstrate that SARS-CoV $3 \mathrm{a} / \mathrm{X} 1$ enhances osteoclast differentiation in a murine osteoclast precursor cell line, RAW264.7. We also demonstrate that $3 \mathrm{a} / \mathrm{X} 1$ induces TNF- $\alpha$ expression in human lung epithelial A549 cells and RANKL expression in mouse bone marrow stromal ST2 cells. These findings imply that osteoclastogenesis accelerated by $3 \mathrm{a} / \mathrm{X} 1$ protein may be involved in the mechanisms of bone abnormalities in patients recovering from SARS, in addition to possible side effects of a steroid therapy.

\section{Materials and methods}

Plasmids

Lentivirus vectors expressing SARS-CoV 3a/X1 (pLenti/ V5/X1) were constructed as described before [16]. Empty vector (pLenti6/V5-DEST, Invitrogen) and enhanced green fluorescent protein (EGFP)-expressing vector (pLenti/V5/ GFP) served as controls. pGEX-X1 was constructed by subcloning a $3 \mathrm{a} / \mathrm{X} 1$-coding EcoRI fragment derived from pLenti/V5/X1 plasmid into pGEX-6P (GE Healthcare) to express $3 \mathrm{a} / \mathrm{X} 1$ protein fused to GST. A reporter plasmid expressing firefly luciferase driven by NF- $\kappa$ B binding sites ( $\kappa$ B-Luc) was provided by Dr. Junichi Fujisawa (Kansai Medical School, Osaka, Japan) [18]. A control plasmid expressing renilla luciferase driven by the cytomegalovirus promoter (pRL-CMV) (Promega) was used as a control.

\section{Cells}

A murine macrophage cell line RAW264.7 [19] has been shown to differentiate into osteoclast-like cells in the presence of RANKL and M-CSF [20]. RAW264.7 cells were cultured in $\alpha$-MEM supplemented with $10 \%$ fetal calf serum (FCS) (Gibco) and antibiotics in an atmosphere containing 5\% $\mathrm{CO}_{2}$. The ST2 cell line, which was derived from mouse bone marrow mesenchymal stem cells and has the ability to differentiate into osteoblast-like cells expressing RANKL in the presence of $1,25(\mathrm{OH})_{2} \mathrm{D}_{3}$ and dexamethasone [9], were purchased from Riken Cell Bank. RAW264.7 and ST2 cells were cultured in $\alpha$-MEM containing 10\% FCS. HEK293T cells derived from human embryo kidney and A549 cells derived from human lung cancer [21] were maintained in Dulbecco's MEM medium containing 10\% FCS. Jurkat cells [22], a human T-cell line, were maintained in RPMI1640 medium containing 10\% FCS. Peripheral blood mononuclear cells (PBMCs) from healthy donors were isolated by Ficoll-Paque PLUS (GE Healthcare UK Ltd., Buckinghamshire, UK) density gradient centrifugation.

\section{Transfection}

For transfection of HEK293T cells with various plasmids, Lipofectamine 2000 (Invirogen) was used. For RAW 264.7 and ST2 cells, electroporation was done using the Amaxa system (Amaxa Inc) in $100 \mu$ l solution V (Amaxa) with the program D-32 (Lonza) or the cells were infected with pseudotyped lentivirus. For A549 cells, both Lipofectoamin and Fugene6 (Roche) were used according to the manufacturer's instructions. For Jurkat cells, electroporation was performed using the Amaxa system in solution $\mathrm{V}$ with the program X-001 (Lonza).

\section{Preparation of a lentiviral expression vector}

Lentiviruses expressing 3a/X1 (VSV-G/pLenti/V5/X1) or GFP (VSV-G/pLenti/V5/GFP) were generated according to the manufacturer's protocol (ViraPower ${ }^{\mathrm{TM}}$ Lentiviral Expression Kit, Invitrogen). Briefly, HEK293T cells $\left(4 \times 10^{6}\right)$ plated in $100-\mathrm{mm}$ dishes were transfected with the pLenti/V5/X1 or pLenti/V5/GFP vector $(5 \mu \mathrm{g})$ together with ViraPower ${ }^{\mathrm{TM}}$ Packaging Mix $(5 \mu \mathrm{g})$, consisting of VSV-G-expression vector, rev-expression vector and gagpol expression vector. After $48 \mathrm{~h}$, culture supernatants were harvested and filtered through $0.45-\mu \mathrm{m}$-pore-size filters. Lentivirus was concentrated $\sim 40$-fold by low-speed centrifugation at $6,000 \times g$ for $16 \mathrm{~h}$, resuspended in $2 \mathrm{ml}$ of RPMI 1640 medium, and stored at $-80^{\circ} \mathrm{C}$ until use.

Flow cytometric analysis

PBMCs $\left(5 \times 10^{5}\right)$ were incubated for $30 \mathrm{~min}$ at $4^{\circ} \mathrm{C}$ with anti-human ACE2 ectodomain antibody monoclonal (mouse $\mathrm{IgG}_{2 \mathrm{~A}}$ ) (R\&D Systems, Inc) or with $\mathrm{LEAF}^{\mathrm{TM}}$ purified mouse IgG2a, $\kappa$ isotype control (BioLegend) in the presence of Fc-blocking reagent, human (Miltenyi Biotec), 
washed twice, and incubated for $30 \mathrm{~min}$ at $4^{\circ} \mathrm{C}$ with goat anti-mouse $\operatorname{IgG}(\mathrm{H}+\mathrm{L})$-RPE, human absorbed (Southern Biotechnology Associates). Cells were washed twice and further incubated with FITC-conjugated mouse anti-human CD14 (BD Pharmingen ${ }^{\mathrm{TM}}$ ), washed twice, and resuspended in $1 \%$ formalin. Samples were analyzed on a FACS Calibur flow cytometer (Becton Dickinson), and data analyses were performed with CellQuest software (Becton Dickinson).

\section{Reporter assays for NF- $\kappa \mathrm{B}$}

Cells $\left(1 \times 10^{7}\right)$ were transfected with NF- $\kappa \mathrm{B}$ reporter plasmids $\kappa \mathrm{B}$-Luc (600 ng), renilla luciferase-expressing pRL-CMV (40 ng) and lentivirus vectors expressing SARS-CoV genes $(5 \mu \mathrm{g})$. Luciferase and renilla luciferase activities were measured from cell lysates $48 \mathrm{~h}$ after transfection using the luciferase assay system and the Renilla luciferase assay system (Promega), respectively.

\section{Western blotting and immunoprecipitation}

Cell pellets $\left(2 \times 10^{6}\right)$ were suspended in $1 \mathrm{ml}$ lysis buffer (10 mM Tris- $\mathrm{HCl}$ [pH 7.4], $2.5 \mathrm{mM} \mathrm{MgCl}_{2}, 100 \mathrm{mM}$ $\mathrm{NaCl}_{2}$ ) containing $0.1 \%$ Nonidet P-40 and protease inhibitor cocktail [CALBIOCHEM, La Jolla, CA]), followed by centrifugation at $10,000 \times g$ for $15 \mathrm{~min}$ at $4^{\circ} \mathrm{C}$. The supernatants were used as cell lysates. For Western blotting, $20 \mu \mathrm{l}$ of cell lysates or culture supernatants were mixed with $5 \mu \mathrm{l} 5 \mathrm{x}$ SDS-sample buffer and treated for $5 \mathrm{~min}$ at $95^{\circ} \mathrm{C}$ and then resolved by SDS-PAGE. Proteins were transferred to a polyvinylidene difluoride membrane and reacted with anti-V5 mouse monoclonal $\mathrm{IgG}_{2 \mathrm{a}}$ (Invitrogen) and sheep anti-mouse Ig-horseradish-peroxidase-linked $\mathrm{F}\left(\mathrm{ab}^{\prime}\right)_{2}$ fragment (Amersham Biosciences), followed by visualization using the enhanced chemiluminescence (ECL) system (Amersham Pharmacia Biotech, Piscataway, NJ, USA) and using an LAS-1000 imaging system (Fuji Photo Fm). For immunoprecipitation, cell lysates or culture supernatants were incubated with anti-V5 mouse monoclonal $\operatorname{IgG}_{2 \mathrm{a}}$ (Invitrogen) for $2 \mathrm{~h}$ and then incubated with $30 \mu \mathrm{l}$ of protein $\mathrm{G}$ agarose (GE Healthcare Bio Sciences AB). Immunoprecipitated proteins were separated from protein $\mathrm{G}$ agarose by heating for $5 \mathrm{~min}$ at $95^{\circ} \mathrm{C}$ in SDSsample buffer prior to Western blotting.

\section{GST-3a/X1 fusion protein}

Competent cells (DH5 $\alpha$; TOYOBO Co., Ltd., Osaka, Japan) transformed by the heat-shock method with pGEX$\mathrm{X} 1$ plasmids, were cultured in 2XYT medium. Protein synthesis was induced by addition of $0.2 \mathrm{mM}$ isopropyl$\beta$-D-thiogalactopyranoside (IPTG) (Wako, Osaka, Japan) overnight at $20^{\circ} \mathrm{C}$. The cells were subsequently centrifuged and suspended in PBS, followed by sonication (3 times for $1 \mathrm{~min})$. The cells were centrifuged at $13,000 \mathrm{rpm}$ for $20 \mathrm{~min}$ at $4^{\circ} \mathrm{C}$, and the supernatants were filtered and stored at $-80^{\circ} \mathrm{C}$ until use.

Osteoclast differentiation

RAW264.7 cells infected with VSV-G/pLenti/V5/X1 or VSV-G/pLenti/V5/GFP pseudotyped lentiviruses were cultured for $48 \mathrm{~h}$, and then $5 \mu \mathrm{l}$ of the cell suspension at a concentration of $2 \times 10^{5}$ cells $/ \mathrm{ml}$ was seeded in the center of the wells of a 24-well plate for spot culture as described elsewhere [23]. After a 30-min incubation, $0.5 \mathrm{ml}$ of growth medium containing $10 \%$ FCS and various concentrations of soluble RANKL (sRANKL, Wako Pure Chemical Industries, Ltd.) was added, and the cells were cultured for 5 days. Cells were then stained for tartrate-resistant acid phosphatase (TRAP) using a TRAP staining kit (Primary Cell Co.,Ltd.) according to the manufacturer's instructions. All of the TRAP-positive cells having more than 3 nuclei in a well were counted under a microscope.

Reverse transcription-polymerase chain reaction (RT-PCR)

Total RNA was extracted from cells using Isogen (Nippon Gene), and cDNA was synthesized from $1.0 \mu \mathrm{g}$ of total RNA by using Rever Tra Ace for RT-PCR (TOYOBO) with oligo $(\mathrm{dT})_{20}$ primers. The cDNA was used as a template for PCR in an amplification mixture containing KOD Dash DNA polymerase and dNTP mix (TOYOBO). PCR cycling conditions consisted of 30 cycles of denaturation at $94^{\circ} \mathrm{C}$ for $30 \mathrm{~s}$, annealing at $60^{\circ} \mathrm{C}$ for $5 \mathrm{~s}$, and extension at $72^{\circ} \mathrm{C}$ for $30 \mathrm{~s}$. The primer sets used were $5^{\prime}$-GGCTCCAG GCGGTGCTTGTTC- $3^{\prime}$ and $5^{\prime}$-AGACGGCGATGCGGCT GATG-3' for human TNF- $\alpha$, 5'-GTGCAAAAGGAAT TACAACATATCGT $-3^{\prime}$ and $5^{\prime}$-AACCATGAGCCATCCA CCAT-3' for human RANKL [24], 5' - GGTGAAGGTCGG AGTCAACGGA- $3^{\prime}$ and $5^{\prime}$-GAGGGATCTCGCTCCTGG AAGA- $3^{\prime}$ for human glyceraldehyde-3-phosphate dehydrogenase (GAPDH), 5'-GGTCGGGCAATTCTGAATT-3' and $5^{\prime}$-GGGGAATTACAAAGTGCACCAG-3' for mouse RANKL [25], and 5'-ACTTTGTCAAGCTCATTT- $3^{\prime}$ and 5'-TGCAGCGAACTTTATTG- $3^{\prime}$ for mouse GAPDH. The predicted sizes of the amplified fragments were $409 \mathrm{bp}$ (human TNF- $\alpha$,), 60 bp (human RANKL), 240 bp (human GAPDH), 813 bp (mouse RANKL), and 210 bp (mouse GAPDH). PCR products were stained with ethidium bromide after $2 \%$ agarose gel electrophoresis, except for human RANKL fragments, which were stained with SYBR green (Lonza) after 10-20\% acrylamide gel electrophoresis. The 
bands of the PCR products were visualized with ultraviolet light and recorded with Coolsaver (ATTO).

Statistical analysis

Student's $t$ test was used for evaluating differences between two groups of samples. $P$ values of $<0.05$ were considered to be statistically significant.

\section{Results and discussion}

Cell-surface expression of ACE2 on primary human monocytes

Angiotensin-converting enzyme 2 (ACE2), a cellular receptor for SARS-CoV [26-28], is expressed on the plasma membrane of respiratory epithelial cells and mediates SARS-CoV infection. At first, we addressed the potential susceptibility of osteoclasts to SARS-CoV infection. Since osteoclasts are derived from $\mathrm{CD}_{1}{ }^{+}$monocytes [29], we examined expression of ACE2 on the surface of CD14 ${ }^{+}$cells in PBMCs by FACS analysis. As shown in Fig. 1, a certain population of peripheral $\mathrm{CD} 14^{+}$monocytes derived from healthy donors expressed ACE2 on the cell surface. Expression of ACE2 in tissue macrophages in atherosclerotic lesions has also been reported recently [30]. Taken together with previous reports showing that macrophages are susceptible to SARS-CoV in vitro [13], we reasoned that osteoclasts could be infected with SARS-CoV during their differentiation from $\mathrm{CD} 14^{+}$monocytes.

\section{Activation of NF- $\kappa$ B by SARS-CoV $3 \mathrm{a} / \mathrm{X} 1$}

in the transient expression system

We previously found that the SARS-CoV accessory protein $3 \mathrm{a} / \mathrm{X} 1$ activated $\mathrm{NF}-\kappa \mathrm{B}$ in epithelial-like HEK293T cells [16]. Shen et al. [31] reported that 3a/X1 was secreted from SARS-CoV-infected Vero E6 cells. We therefore examined whether $3 \mathrm{a} / \mathrm{X} 1$ protein secreted from cells could induce $\mathrm{NF}-\kappa \mathrm{B}$ activation when exogenously added to cells. As shown in Fig. 2, substantial amounts of $3 \mathrm{a} / \mathrm{X} 1$ were detected not only in cell lysates (Fig. 2a) but also in the culture supernatants (Fig. 2b) of HEK293T cells following transfection with $\mathrm{pLenti} / \mathrm{V} 5 / \mathrm{X} 1$ plasmids, reproducing the secretion properties of $3 \mathrm{a} / \mathrm{X} 1$. Then, the biological function of the secreted form of $3 \mathrm{a} / \mathrm{X} 1$ was addressed using a NF- $\kappa \mathrm{B}$ reporter assay. We observed significant activation of NF$\kappa \mathrm{B}$ by direct transfection of the $3 \mathrm{a} / \mathrm{X} 1$ expression vector, but not by addition of the culture supernatant containing the secreted form of $3 \mathrm{a} / \mathrm{X} 1$ (Fig. 2c). We also prepared a GST-3a/X1 fusion protein. As shown in Fig. 2d, although E. coli extracts contained substantial amounts of GST-3a/ $\mathrm{X} 1$ fusion protein, its effect on enhancement of $\mathrm{NF}-\kappa \mathrm{B}$ activity in HEK293T was minimal. Thus, 3a/X1 could activate $\mathrm{NF}-\kappa \mathrm{B}$ when expressed inside cells, but less effectively in a secreted form, at least in HEK293T cells.

The activation of the $\mathrm{NF}-\kappa \mathrm{B}$ through $3 \mathrm{a} / \mathrm{X} 1$ was then examined in a murine osteoclast precursor cell line, RAW 264.7 cells $[19,20]$. We transfected RAW264.7 cells with pLenti/V5/X1 or pLenti/V5/GFP (irrelevant control) by elecroporation. As shown in Fig. $3, \mathrm{NF}-\kappa \mathrm{B}$ activity was significantly augmented by $3 \mathrm{a} / \mathrm{X} 1$ expression, but not by GFP expression in RAW264.7 cells.

\section{Augmentation of osteoclast differentiation} by SARS-CoV 3a/X1

To address possible effects of the $3 \mathrm{a} / \mathrm{X} 1$ during osteoclast formation, we employed a lentiviral transduction system for forced expression of $3 a / X 1$. Expression of $3 a / X 1$ in RAW264.7 cells infected with VSV-G/pLenti/V5/X1 pseudotyped viruses was confirmed by Western blot analysis (Fig. 4a). At 48 h postinfection, RAW264.7 cells were transferred to further culture with or without sRANKL for 5 days, and then osteoclast formation was evaluated under a microscope after TRAP staining. As shown in Fig. 4b, the number of $\mathrm{TRAP}^{+}$osteoclasts was higher in the cells
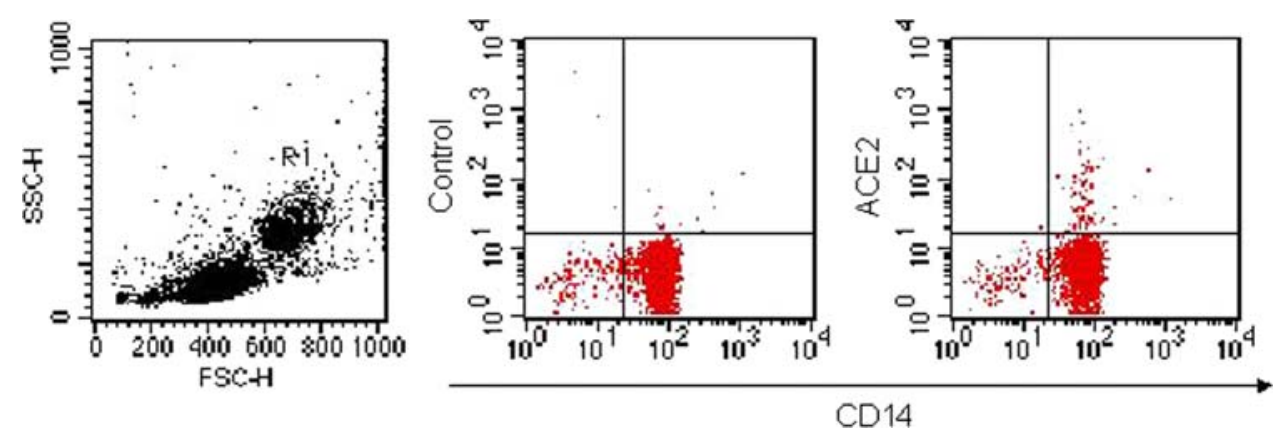

Fig. 1 Expression of ACE2 on primary human monocytes. PBMCs from a healthy donor were stained with anti-human ACE2 ectodomain $\mathrm{mAb}$ (right) or isotype control antibody (middle) and subsequently with goat anti-mouse $\operatorname{IgG}(\mathrm{H}+\mathrm{L})$-RPE, followed by staining with FITC-anti-human CD14 mAb. The monocyte fraction was gated (left panel) and analyzed by two-color flow cytometry 

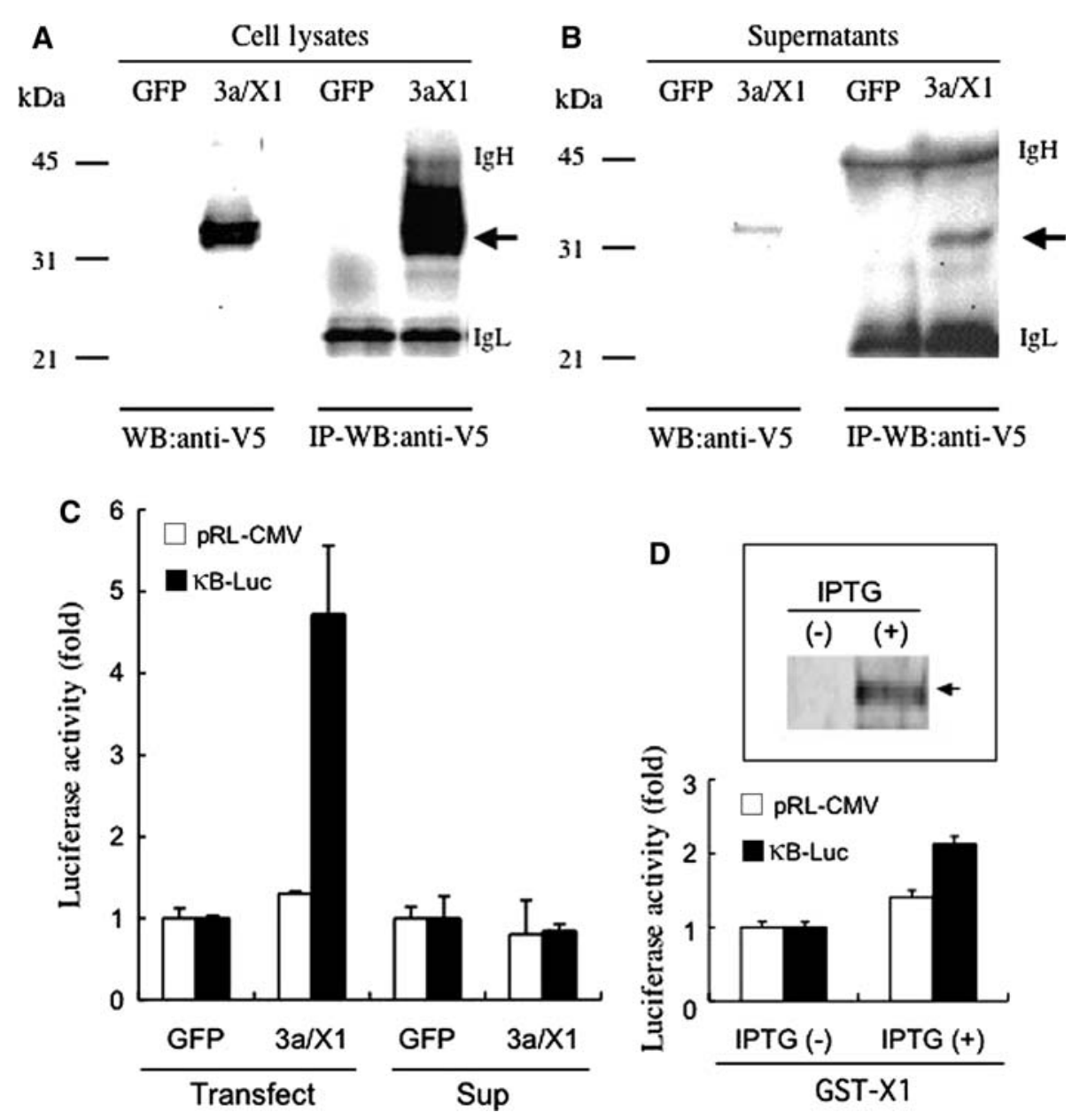

Fig. 2 Secretion of SARS-CoV 3a/X1 from cells. (a, b) Cell lysates (a) and culture supernatants (b) from HEK293T cells that had been transfected with pLenti/V5/GFP (GFP) or pLenti/V5/X1 (3a/X1) $48 \mathrm{~h}$ earlier were subjected to Western blot (WB) analysis with anti-V5 antibody directly (WB) or following immunoprecipitation with the same antibody (IP-WB). Arrows indicate the sizes of $3 \mathrm{a} / \mathrm{X} 1$. Sizes of immunoglobulin heavy (IgH) and light chains (IgL) are also indicated. (c) Effects on NF- $\kappa \mathrm{B}$ activity of direct expression of $3 \mathrm{a} /$ $\mathrm{X} 1$ (Transfect) and soluble 3a/X1 (Sup). For the direct expression experiment, HEK293T cells were co-transfected with NF- $\kappa \mathrm{B}$ reporter plasmid ( $\kappa \mathrm{B}$-Luc) (closed bar), pRL-CMV (open bar), and pLenti/ V5/GFP (GFP) or pLenti/V5/X1 (3a/X1), followed by $48 \mathrm{~h}$ culture (Transfect). For the soluble-3a/X1 experiment, $\kappa \mathrm{B}$-Luc (closed bar)or pRL-CMV (open bar)-transfected HEK293T cells were cultured for $24 \mathrm{~h}$ in the culture supernatants of separately prepared HEK293T

transduced with $3 \mathrm{a} / \mathrm{X} 1$ than in the control cells transduced with GFP. The $3 \mathrm{a} / \mathrm{X} 1$-mediated enhancement of osteoclast formation was observed in the presence of sRANKL at both optimal $(50 \mathrm{ng} / \mathrm{ml})$ and suboptimal $(25 \mathrm{ng} / \mathrm{ml})$ concentrations, although the difference was statistically significant only at the concentration of $50 \mathrm{ng} / \mathrm{ml}$. In the absence of sRANKL, expression of $3 \mathrm{a} / \mathrm{X} 1$ alone was not sufficient to induce osteoclast differentiation. The TRAP ${ }^{+}$ cells observed in cultures containing sRANKL exhibited large and multinuclear phenotypes similar to those of cells that had been transfected with pLenti/V5/GFP (GFP) or pLenti/ V5/X1 (3a/X1) $48 \mathrm{~h}$ earlier (Sup). Luciferase activities in cell lysates were indicated as fold increases against GFP controls. (d) Crude GST-3a/X1 fusion proteins were extracted from E. coli transformed with pGEX-X1 as described in Materials and methods. GST-3a/X1 fusion proteins in the E. coli extracts with or without IPTG treatment were detected by Western blot using antibodies to GST (top panel). Arrows indicate the sizes of GST-3a/X1 fusion protein $(63 \mathrm{kD})$. These extracts $(50 \mu \mathrm{l} /$ well $)$ were added to separately prepared HEK293T cells that had been transfected with $\kappa \mathrm{B}$-Luc (closed bar) and pRLCMV (open bar) plasmids the day before. Luciferase activities in cell lysates were measured after a $24-\mathrm{h}$ incubation. The data represent fold increases against the control sample incubated with $E$. coli extracts without IPTG induction, and indicated as the mean \pm SD of duplicate samples

mature osteoclasts, irrespective of the lentiviruses (Fig. 4c). These results indicate that osteoclast differentiation can be enhanced by SARS-CoV 3a/X1 in cooperation with sRANKL.

Effects of $3 \mathrm{a} / \mathrm{X} 1$ on expression of TNF- $\alpha$ and RANKL mRNA

The differentiation of osteoclasts from their precursor cells requires interaction with osteoblasts in the bone marrow, 


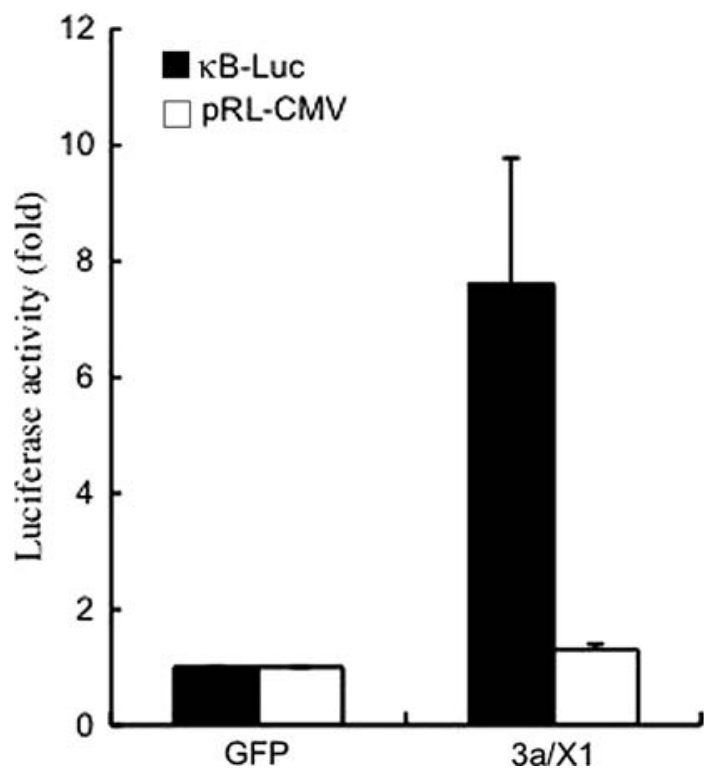

Fig. 3 Activation of NF- $\kappa$ B by SARS-CoV $3 a / X 1$ in RAW264.7cells. The NF- $\kappa \mathrm{B}$ reporter plasmid ( $\kappa \mathrm{B}$-Luc) (closed bar) and pRLCMV (open bar) were introduced together with pLenti/V5/X1 (3a/ X1) or control pLenti/V5/GFP (GFP) vectors into RAW264.7cells by transfection, and luciferase activities were measured approximately $48 \mathrm{~h}$ after transfection. Data represent means \pm S.D. of fold increases against GFP controls in three independent experiments which express RANKL [7]. Inflammatory cytokines such as TNF- $\alpha$ also promote osteoclastogenesis in the presence of RANKL $[11,12]$. Finally, we addressed the effect of the $3 \mathrm{a} / \mathrm{X} 1$ on RANKL and TNF- $\alpha$ expression. For this purpose, we employed A549 cells derived from human lung cancer, as we found that A549 cells expressed ACE2 (Fig. 5a). We then transfected A549 cells with pLenti/V5/X1 and evaluated TNF- $\alpha$ and RANKL mRNA expression by RT-PCR. As shown in Fig. 5b, the level of TNF- $\alpha$ transcripts was significantly increased by expression of $3 \mathrm{a} / \mathrm{X} 1$, whereas RANKL expression remained at a low level. We also examined the effects of $3 \mathrm{a} / \mathrm{X} 1$ on RANKL expression in human T-cell line Jurkat cells and mouse bone marrow stromal ST2 cells, as both cell lines have been reported to express RANKL upon stimulation $[9,32]$. In Jurkat cells, stimulation with phorbol 12-myristate 13-acetate (PMA) and ionomycin, but not 3a/X1, induced RANKL mRNA expression (Fig. 5c). In ST2 cells, however, 3a/X1 enhanced RANKL mRNA expression (Fig. 5d). These findings suggest that $3 \mathrm{a} / \mathrm{X} 1$ has a strong ability to induce TNF- $\alpha$ expression in epithelial cells and might potentially enhance RANKL expression through indirect mechanisms in some stromal cells.

RANK-stimulation by RANKL activates NF- $\kappa$ B and JNK pathways [33], both of which are also activated by
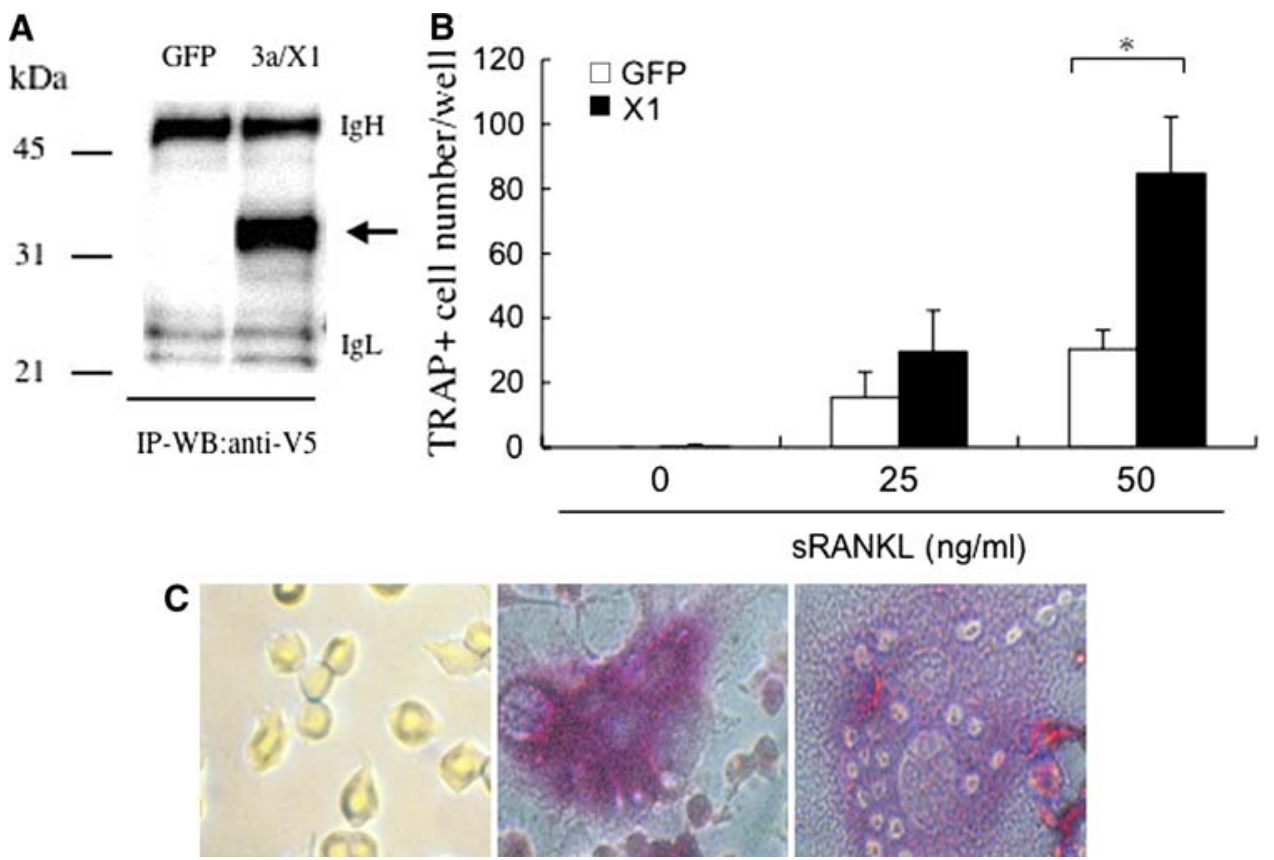

Fig. 4 Augmentation of osteoclast differentiation by SARS-CoV 3a/ $\mathrm{X} 1$. a RAW264.7 cells were infected with pseudotyped viruses expressing 3a/X1 (VSV-G/pLenti/V5/X1) or GFP (VSV-G/pLenti/ V5/GFP), and the cell lysates $48 \mathrm{~h}$ after infection were subjected to Western blot analysis with anti-V5 antibody after immunoprecipitation with the same antibody. Arrows indicate the size of $3 \mathrm{a} / \mathrm{X} 1$. b RAW264.7 cells were infected with VSV-G/pLenti/V5/GFP (open bar) or VSV-G/pLenti/V5/X1 (closed bar) pseudotyped viruses for
$48 \mathrm{~h}$, and 1,000 cells/spot were further cultured for 5 days with sRANKL at the indicated concentrations. The cells were stained with TRAP, and the osteoclast-like $\mathrm{TRAP}^{+}$multinuclear cells in each well were counted under a microscope. Data are expressed as means $\pm \mathrm{SD}$ of triplicate wells. ${ }^{*} p<0.05$. c Representative images after TRAP staining of untreated RAW264.7 cells (left) and VSV-G/pLenti/V5/ GFP-infected (middle) or VSV-G/pLenti/V5/X1-infected (right) RAW264.7 cells in the presence of $50 \mathrm{ng} / \mathrm{ml} \mathrm{sRANKL}$ 

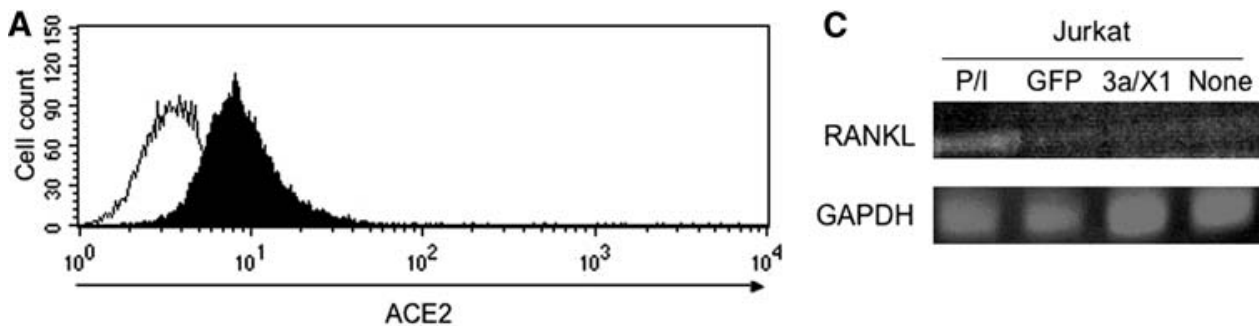

B

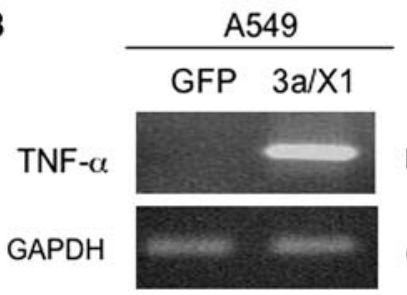

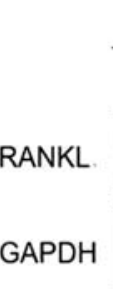

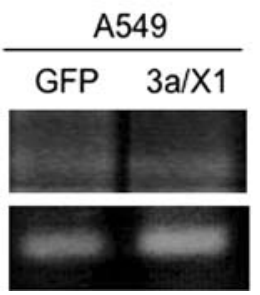

D

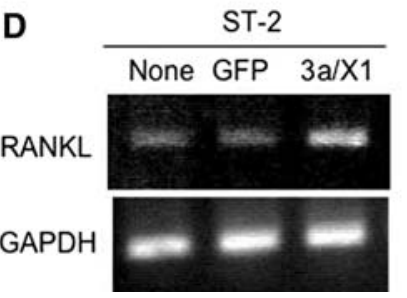

Fig. 5 Effects of $3 \mathrm{a} / \mathrm{X} 1$ on TNF- $\alpha$ and RANKL mRNA expression. a Expression of ACE2 in A549 cells was evaluated by flow cytometry after staining with anti-human ACE2 mAb (closed histogram) or isotype-matched control antibody (open histogram) and subsequently, with goat anti-mouse IgG (H + L)-RPE. b A549 cells were transfected with pLenti6/V5/GFP (GFP) or pLenti/V5/X1 (3a/X1), and total RNA samples $(1 \mu \mathrm{g})$ extracted from these cells $48 \mathrm{~h}$ after transfection were subjected to 30 cycles of RT-PCR with primers specific for TNF- $\alpha$, RANKL, and GAPDH as indicated. PCR products were visualized by staining with ethidium bromide or SYBR green following gel electrophoresis. c Jurkat cells transfected with pLenti6/ V5/GFP (GFP) or pLenti/V5/X1 (3a/X1) were subjected to RT-PCR with RANKL- or GAPDH-specific primers $48 \mathrm{~h}$ after transfection. Jurkat cells treated without (None) or with PMA (10 ng/ml) and ionomycin $(750 \mathrm{ng} / \mathrm{ml})(\mathrm{P} / \mathrm{I})$ for $16 \mathrm{~h}$ served as negative and positive controls, respectively. d ST2 cells transfected without (None) or with pLenti6/V5/GFP (GFP) or pLenti/V5/X1 (3a/X1) were subjected to RT-PCR with primers specific for mouse RANKL and GAPDH $72 \mathrm{~h}$ after transfection
SARS-CoV 3a/X1 expression [16]. The common pathways downstream from these two molecules explain the enhancement of osteoclastogenesis by $3 \mathrm{a} / \mathrm{X} 1$ expression in concert with RANKL. Since circulating monocytes express ACE2, SARS-CoV infection of these cells may accelerate differentiation to osteoclasts accumulating in the bones. In addition, we found that $3 \mathrm{a} / \mathrm{X} 1$ induced TNF- $\alpha$ transcription in lung-cancer-derived epithelial A549 cells expressing ACE2. This is consistent with the notion that $3 \mathrm{a} / \mathrm{X} 1 \mathrm{might}$ be involved in the robust inflammatory cytokine production in SARS patients. 3a/X1 enhanced RANKL expression in ST2 cells but not in A549 or Jurkat cells, suggesting that RANKL up-regulation in ST2 cells by $3 \mathrm{a} / \mathrm{X} 1$ might represent indirect effects. It has been reported that inflammatory cytokines such as IL-1 and TNF- $\alpha$ induce RANKL expression in synovial fibroblasts [34].

In conclusion, SARS-CoV $3 \mathrm{a} / \mathrm{X} 1$ potentially promotes osteoclastogenesis by accelerating osteoclast differentiation from precursor monocytes/macrophages, and also indirectly through TNF- $\alpha$ and the RANK/RANKL system. These findings partly explain the unusual bone abnormalities observed in patients following recovery from SARS.

Acknowledgment This study was supported by the Special Coordination Funds for Promoting Science and Technology of Japan Science and Technology.

\section{References}

1. WHO (2004) WHO guidelines for the global surveillance of severe acute respiratory syndrome (SARS). Epidemic Alert and Response: October

2. Donnelly CA, Ghani AC, Leung GM, Hedley AJ, Fraser C, Riley S, Abu-Raddad LJ, Ho LM, Thach TQ, Chau P, Chan KP, Lam TH, Tse LY, Tsang T, Liu SH, Kong JH, Lau EM, Ferguson NM, Anderson RM (2003) Epidemiological determinants of spread of causal agent of severe acute respiratory syndrome in Hong Kong. Lancet 361:1761-1766

3. Peiris JS, Yuen KY, Osterhaus AD, Stohr K (2003) The severe acute respiratory syndrome. N Engl J Med 349:2431-2441

4. Nicholls JM, Poon LL, Lee KC, Ng WF, Lai ST, Leung CY, Chu CM, Hui PK, Mak KL, Lim W, Yan KW, Chan KH, Tsang NC, Guan Y, Yuen KY, Peiris JS (2003) Lung pathology of fatal severe acute respiratory syndrome. Lancet 361:1773-1778

5. Lau EM, Chan FW, Hui DS, Wu AK, Leung PC (2005) Reduced bone mineral density in male severe acute respiratory syndrome (SARS) patients in Hong Kong. Bone 37:420-424

6. Griffith JF, Antonio GE, Kumta SM, Hui DS, Wong JK, Joynt GM, Wu AK, Cheung AY, Chiu KH, Chan KM, Leung PC, Ahuja AT (2005) Osteonecrosis of hip and knee in patients with severe acute respiratory syndrome treated with steroids. Radiology 235:168-175

7. Theill LE, Boyle WJ, Penninger JM (2002) RANK-L and RANK: $\mathrm{T}$ cells, bone loss, and mammalian evolution. Annu Rev Immunol 20:795-823

8. Lacey DL, Timms E, Tan HL, Kelley MJ, Dunstan CR, Burgess T, Elliott R, Colombero A, Elliott G, Scully S, Hsu H, Sullivan J, Hawkins N, Davy E, Capparelli C, Eli A, Qian YX, Kaufman S, Sarosi I, Shalhoub V, Senaldi G, Guo J, Delaney J, Boyle WJ 
(1998) Osteoprotegerin ligand is a cytokine that regulates osteoclast differentiation and activation. Cell 93:165-176

9. Yasuda H, Shima N, Nakagawa N, Yamaguchi K, Kinosaki M, Mochizuki S, Tomoyasu A, Yano K, Goto M, Murakami A, Tsuda E, Morinaga T, Higashio K, Udagawa N, Takahashi N, Suda T (1998) Osteoclast differentiation factor is a ligand for osteoprotegerin/osteoclastogenesis-inhibitory factor and is identical to TRANCE/RANKL. Proc Natl Acad Sci USA 95:3597-3602

10. Komano Y, Nanki T, Hayashida K, Taniguchi K, Miyasaka N (2006) Identification of a human peripheral blood monocyte subset that differentiates into osteoclasts. Arthritis Res Ther 8:R152. doi:10.1186/ar2046

11. Lam J, Takeshita S, Barker JE, Kanagawa O, Ross FP, Teitelbaum SL (2000) TNF-alpha induces osteoclastogenesis by direct stimulation of macrophages exposed to permissive levels of RANK ligand. J Clin Invest 106:1481-1488

12. Xing L, Schwarz EM, Boyce BF (2005) Osteoclast precursors, RANKL/RANK, and immunology. Immunol Rev 208:19-29

13. Cheung CY, Poon LL, Ng IH, Luk W, Sia SF, Wu MH, Chan KH, Yuen KY, Gordon S, Guan Y, Peiris JS (2005) Cytokine responses in severe acute respiratory syndrome coronavirusinfected macrophages in vitro: possible relevance to pathogenesis. J Virol 79:7819-7826

14. Rota PA, Oberste MS, Monroe SS, Nix WA, Campagnoli R, Icenogle JP, Penaranda S, Bankamp B, Maher K, Chen MH, Tong S, Tamin A, Lowe L, Frace M, DeRisi JL, Chen Q, Wang D, Erdman DD, Peret TC, Burns C, Ksiazek TG, Rollin PE, Sanchez A, Liffick S, Holloway B, Limor J, McCaustland K, OlsenRasmussen M, Fouchier R, Gunther S, Osterhaus AD, Drosten C, Pallansch MA, Anderson LJ, Bellini WJ (2003) Characterization of a novel coronavirus associated with severe acute respiratory syndrome. Science 300:1394-1399

15. Marra MA, Jones SJ, Astell CR, Holt RA, Brooks-Wilson A, Butterfield YS, Khattra J, Asano JK, Barber SA, Chan SY, Cloutier A, Coughlin SM, Freeman D, Girn N, Griffith OL, Leach SR, Mayo M, McDonald H, Montgomery SB, Pandoh PK, Petrescu AS, Robertson AG, Schein JE, Siddiqui A, Smailus DE, Stott JM, Yang GS, Plummer F, Andonov A, Artsob H, Bastien N, Bernard K, Booth TF, Bowness D, Czub M, Drebot M, Fernando L, Flick R, Garbutt M, Gray M, Grolla A, Jones S, Feldmann H, Meyers A, Kabani A, Li Y, Normand S, Stroher U, Tipples GA, Tyler S, Vogrig R, Ward D, Watson B, Brunham RC, Krajden M, Petric M, Skowronski DM, Upton C, Roper RL (2003) The Genome sequence of the SARS-associated coronavirus. Science 300:1399-1404

16. Kanzawa N, Nishigaki K, Hayashi T, Ishii Y, Furukawa S, Niiro A, Yasui F, Kohara M, Morita K, Matsushima K, Le MQ, Masuda T, Kannagi M (2006) Augmentation of chemokine production by severe acute respiratory syndrome coronavirus $3 \mathrm{a} / \mathrm{X} 1$ and $7 \mathrm{a} / \mathrm{X} 4$ proteins through NF-kappaB activation. FEBS Lett 580:6807-6812

17. Narayanan K, Huang C, Makino S (2008) SARS coronavirus accessory proteins. Virus Res 133:113-121

18. Hirai H, Suzuki T, Fujisawa J, Inoue J, Yoshida M (1994) Tax protein of human T-cell leukemia virus type I binds to the ankyrin motifs of inhibitory factor kappa B and induces nuclear translocation of transcription factor NF-kappa B proteins for transcriptional activation. Proc Natl Acad Sci USA 91:3584-3588

19. Ralph P, Nakoinz I (1977) Antibody-dependent killing of erythrocyte and tumor targets by macrophage-related cell lines: enhancement by PPD and LPS. J Immunol 119:950-954

20. Hsu H, Lacey DL, Dunstan CR, Solovyev I, Colombero A, Timms E, Tan HL, Elliott G, Kelley MJ, Sarosi I, Wang L, Xia
XZ, Elliott R, Chiu L, Black T, Scully S, Capparelli C, Morony S, Shimamoto G, Bass MB, Boyle WJ (1999) Tumor necrosis factor receptor family member RANK mediates osteoclast differentiation and activation induced by osteoprotegerin ligand. Proc Natl Acad Sci USA 96:3540-3545

21. Giard DJ, Aaronson SA, Todaro GJ, Arnstein P, Kersey JH, Dosik H, Parks WP (1973) In vitro cultivation of human tumors: establishment of cell lines derived from a series of solid tumors. J Natl Cancer Inst 51:1417-1423

22. Gillis S, Watson J (1980) Biochemical and biological characterization of lymphocyte regulatory molecules. V: identification of an interleukin 2-producing human leukemia T cell line. J Exp Med 152:1709-1719

23. Hayashi H, Nakahama K, Sato T, Tuchiya T, Asakawa Y, Maemura T, Tanaka M, Morita M, Morita I (2008) The role of Mac-1 (CD11b/CD18) in osteoclast differentiation induced by receptor activator of nuclear factor-kappaB ligand. FEBS Lett 582:3243-3248

24. Nenseter MS, Ueland T, Retterstol K, Strom E, Morkrid L, Landaas S, Ose L, Aukrust P, Holven KB (2009) Dysregulated RANK ligand/RANK axis in hyperhomocysteinemic subjects: effect of treatment with B-vitamins. Stroke 40:241-247

25. Tsubaki M, Kato C, Manno M, Ogaki M, Satou T, Itoh T, Kusunoki T, Tanimori Y, Fujiwara K, Matsuoka H, Nishida S (2007) Macrophage inflammatory protein-1alpha (MIP-1alpha) enhances a receptor activator of nuclear factor kappaB ligand (RANKL) expression in mouse bone marrow stromal cells and osteoblasts through MAPK and PI3 K/Akt pathways. Mol Cell Biochem 304:53-60

26. Li W, Moore MJ, Vasilieva N, Sui J, Wong SK, Berne MA, Somasundaran M, Sullivan JL, Luzuriaga K, Greenough TC, Choe H, Farzan M (2003) Angiotensin-converting enzyme 2 is a functional receptor for the SARS coronavirus. Nature 426:450-454

27. Dimitrov DS (2003) The secret life of ACE2 as a receptor for the SARS virus. Cell 115:652-653

28. Xiao X, Chakraborti S, Dimitrov AS, Gramatikoff K, Dimitrov DS (2003) The SARS-CoV S glycoprotein: expression and functional characterization. Biochem Biophys Res Commun 312:1159-1164

29. Sorensen MG, Henriksen K, Schaller S, Henriksen DB, Nielsen FC, Dziegiel MH, Karsdal MA (2007) Characterization of osteoclasts derived from CD14+ monocytes isolated from peripheral blood. J Bone Miner Metab 25:36-45

30. Sluimer JC, Gasc JM, Hamming I, van Goor H, Michaud A, van den Akker LH, Jutten B, Cleutjens J, Bijnens AP, Corvol P, Daemen MJ, Heeneman S (2008) Angiotensin-converting enzyme 2 (ACE2) expression and activity in human carotid atherosclerotic lesions. J Pathol 215:273-279

31. Shen S, Lin PS, Chao YC, Zhang A, Yang X, Lim SG, Hong W, Tan YJ (2005) The severe acute respiratory syndrome coronavirus $3 \mathrm{a}$ is a novel structural protein. Biochem Biophys Res Commun 330:286-292

32. Belibasakis GN, Brage M, Lagergard T, Johansson A (2008) Cytolethal distending toxin upregulates RANKL expression in Jurkat T-cells. Apmis 116:499-506

33. Boyle WJ, Simonet WS, Lacey DL (2003) Osteoclast differentiation and activation. Nature 423:337-342

34. Takayanagi H, Iizuka H, Juji T, Nakagawa T, Yamamoto A, Miyazaki T, Koshihara Y, Oda H, Nakamura K, Tanaka S (2000) Involvement of receptor activator of nuclear factor kappaB ligand/osteoclast differentiation factor in osteoclastogenesis from synoviocytes in rheumatoid arthritis. Arthritis Rheum 43: 259-269 